\title{
PENELITIAN ARKEOLOGI BAWAH AIR DI INDONESIA TANTANGAN, PELUANG, DAN ARAH KEBIJAKAN PENELITIAN ARKEOLOGI MARITIM ${ }^{3}$
}

\author{
Siswanto \\ (Balai Arkeologi Yogyakarta)
}

\begin{abstract}
In Indonesia, underwater archaeology as a part of maritime study seems to be isolated, because the study has not yet made significant contribution to the understanding of maritime life ways in the archipelago. Various archaeological data needed to reveal the history of human settlement, insular trade, maritime history, migration, and other aspects of maritime culture in the archipelago are still concealed at the bottom of the sea or rivers. On the other hand, the development of underwater archeology in Indonesia is still left far behind compared to other Southeast Asian countries, so the abundant underwater archaeological data are still unreachable. So far, the existing underwater archaeology activities carried out within this largest archipelagic country are still aimed at exploring underwater "treasure", with very limited concern on archaeological research. On another side, it is certainly aware that a"real" underwater archaeological research require the readiness of both human resources as well as the supporting equipments. Therefore, to develop more proper underwater archaeological activities, it is necessary to establish clear and executable policies and strategy, e.g by improving the quality and quantity of resources, establishing networking, and conducting other potential activities periodically, consistently, with high discipline.
\end{abstract}

melangkahkan satu langkah ke depan akan lebih baik daripada hanya membicarakan rencana seribu langkah. (motivator Mario Teguh)

\section{PENDAHULUAN}

Hingga saat ini, kita belum bisa menyusun kembali dengan pasti tahap-tahap penghunian Nusantara pada awal mula sejarahnya. Namun, sudah jelas bahwa pada kurun waktu seribu tahun pertama sebelum Masehi daerah ini sudah termasuk suatu kawasan budaya besar, yang mengandaikan adanya hubungan laut yang tetap (Lombard, 2005). Ungkapan Denys Lombard tersebut menjadi tantangan bagi studi arkeologi

3 Pernah dipresentasikan pada Seminar Evaluasi Hasil Penelitian Arkeologi, Sanur, Denpasar - Bali, 2-5 November 2009

Berkala Arkeologi Tafun XXX Edisi $\mathcal{N}_{0.1}$ / Mei 2010 
maritim maupun ilmu lain untuk mengungkap sejarah hunian manusia di Nusantara ini. Kenyataannya, sampai saat ini masih banyak bingkai-bingkai yang kosong tentang sejarah hunian, sejarah perdagangan insuler, sejarah pelayaran, dan migrasi di Nusantara. Bingkai-bingkai kosong yang harus diisi dan pertanyaan harus dijawab, sedangkan jawaban-jawaban diantaranya sekarang masih banyak tersimpan di dalam laut.

Dalam konteks sejarah panjang penghunian manusia di Nusantara, tantangan yang muncul adalah pembuktian adanya pergerakan atau migrasi manusia purba. Banyak ahli berpendapat bahwa migrasi manusia purba telah berlangsung tidak hanya ribuan tahun lalu tetapi sejak ratusan ribu tahun yang lalu. Tanudirjo (2008) memaparkan bahwa Homo erectus sebagai manusia tertua penghuni Pulau Jawa ketika itu bahkan telah hidup di Pulau Flores pada sekitar 800.000 tahun yang lalu. Diyakini waktu itu mereka telah memiliki teknologi pelayaran sederhana sehingga dapat berlayar menyeberangi selat-selat sempit di antara pulau-pulau besar di daerah ini, terutama di sebelah timur Paparan Sunda. Diduga Homo erectus telah mampu merakit bambu menjadi perahu sederhana yang cukup handal untuk menyeberangi selat yang berjarak beberapa puluh meter pada musim-musim laut tenang. Lebih lanjut Tanudirjo (2008) mengungkapkan bahwa persebaran manusia dari satu pulau ke pulau lain tidak mungkin dapat dilakukan apabila teknologi pelayaran yang dikuasai manusia tidak cukup handal. Sayang sekali hingga saat ini belum ada data arkeologis yang dapat dipakai merekonstruksi teknologi pelayaran yang berkembang pada kala itu.

Sesungguhnya penelitian arkeologi bawah air (underwater archaeology) maupun penelitian arkeologi di atas air (darat) pada intinya mempunyai niat atau tujuannya tidak berbeda, yaitu untuk menggali informasi tentang budaya masyarakat masa lalu, menyusun sejarah kebudayaan, merekonstruksi cara-cara hidup maupun proses perubahan kebudayaan melalui benda-benda yang ditinggalkan manusia. Hanya saja karena keberadaan benda yang menjadi objek penelitian tersebut berbeda antara di darat dan di dalam air maka diperlukan metode, cara, dan teknik yang berbeda pula.

Arkeologi bawah air merupakan bagian dari arkeologi maritim (mantime archaeology) yaitu suatu ilmu yang mempelajari aktivitas manusia masa lalu yang berhubungan dengan laut. Lebih jauh Green (2004) menguraikan bahwa arkeologi maritim menjadi bagian dari arkeologi. Dengan demikian merupakan suatu disiplin yang ilmiah. Arkeologi maritim mempunyai tatacara kerja yang sederhana. Pertama-tama tentu Arkeologi maritim harus bekerja sistematis. Selanjutnya, informasi yang diperoleh harus direkam sebanyak-banyaknya dan didokumentasikan dengan baik, dan akhirnya pekerjaan harus secara penuh dianalisa lalu diterbitkan. Dalam penelitian yang melibatkan penggalian, material yang didapat harus dipelihara dengan baik sehingga dapat dipelajari di masa datang dan diterbitkan, terutama dalam bentuk laporan dari suatu penggalian 
(ekskavasi). Koleksi harus disimpan dengan rapi dan terpadu, dalam rangka menjamin penyimpanan dan kelestariannya untuk jangka panjang.

Anggapan umum bahwa penelitian arkeologi bawah air sama dengan kegiatan pengangkatan harta karun adalah sangat keliru. Pengangkatan harta karun dari bangkai kapal tenggelam biasanya cenderung bertujuan mendapatkan isi maupun bagian kapal yang bemilai ekonomi, sedangkan penelitian arkeologi bawah air tidak harus mengangkat benda-benda arkeologi bawah air dan tidak memilih hanya yang bernilai ekonomi. Dalam penelitian arkeologi bawah air, yang diangkat utamanya adalah nilai ilmiahnya berupa data atau informasi yang melekat pada benda-benda tersebut. Hal ini dilakukan untuk mempelajari dan mengungkapkan aktivitas masyarakat masa lampau berkaitan dengan laut sebagaimana tujuan disiplin arkeologi maritim. Kegiatan pengangkatan harta karun dan penelitian arkeologi bawah air mempunyai tujuan berbeda walaupun bisa dilaksanakan bersama-sama.

Penelitian arkeologi bawah air di Indonesia hingga kini belum menunjukkan hasil yang berarti, bahkan dapat dikatakan belum benar-benar dilakukan, seolah sedang tidur panjang. Apa yang telah dilakukan selama ini, baik oleh arkeolog maupun pihak lain, tidak lebih dari survei penjajagan lokasi perahu-perahu tenggelam (shipwrecks) dan penelitian arkeologi maritim. Akhir-akhir ini, antara tahun $2004-2005$, ada beberapa kegiatan arkeologi bawah air yang dilakukan pihak swasta, antara lain pengangkatan benda arkeologis bawah air di perairan utara Cirebon (Laut Jawa). Namun, kegiatan tersebut tujuannya lebih diutamakan pada pengangkatan harta karun atau Benda berharga asal Muatan Kapal Tenggelam (BMKT).

Perkembangan arkeologi bawah air di Indonesia sebenamya telah mulai dirintis pada dekade 1980-an, yang dimulai dengan pengiriman beberapa arkeolog Indonesia untuk tergabung dalam SEAMEO Project in Archaeology and Fine Art (SPAFA) di Thailand. Penanganan sumber daya arkeologi di perairan Indonesia sudah mulai bangkit saat itu. Ada kesadaran bahwa sumber daya arkeologi di bawah perairan Nusantara begitu banyak dan mengundang pengambilan secara illegal. Seiring dengan pencetakan tenaga terlatih, terutama untuk penyelaman, Departemen Pendidikan dan Kebudayaan membentuk Seksi Pengendalian Peninggalan Bawah Air yang bertugas mengurusi peninggalan sumber daya budaya bawah air dalam lingkungan Direktorat Jenderal Kebudayaan. Namun, peristiwa hilangnya arkeolog bawah air dalam kegiatan penelisikan pengangkatan harta karun kapal Geldermalsen milik VOC di perairan Riau pada tahun 1985-1986 seolah menjadi titik awal "tenggelamnya" atau tidurnya pengelolaan arkeologi bawah air Indonesia. Selanjutnya, karena tenaga terlatih terbatas, kebutuhan anggaran yang besar, keterbatasan peralatan untuk pengangkatan peninggalan bawah air, serta adanya insiden hilangnya seorang perintis arkeologi bawah air, maka semangat pengelolaan benda purbakala di bawah air di Indonesia menjadi kendur.

Kebangkitan kembali arkeologi bawah air di Indonesia saat ini mulai dirasakan dengan adanya institusi pemerintah yang menangani khusus 
sumber daya budaya bawah air, yaitu Direktorat Peninggalan Bawah Air di lingkungan Direktorat Jenderal Sejarah dan Purbakala Departemen Kebudayaan dan Pariwisata. Kegiatan lembaga baru tersebut bisa disebut memulai dari awal, dimana hal yang paling mendesak adalah penyiapan ketrampilan sumber daya manusia, yaitu melakukan kegiatan pendidikan dan pelatihan dalam rangka pengembangan dan pencetakan sumber daya manusia di bidang arkeologi bawah air. Selanjutnya lembaga ini perlu menerbitkan aturan-aturan atau regulasi-regulasi dan silabus pengelolaan peninggalan bawah air. Kebangkitan dari tidur panjang pengelolaan arkeologi bawah air di Indonesia akhir-akhir ini semakin terasa dengan munculnya berbagai minat perorangan maupun lembaga yang peduli terhadap peninggalan bawah air.

\section{POTENSI OBYEK PENELITIAN ARKEOLOGI BAWAH AIR}

Arkeologi bawah air secara khusus ditujukan untuk kegiatan penelitian arkeologi di perairan Indonesia dapat dikatakan belum pernah dilakukan. Underwater archaeology selama ini masih sebatas pengangkatan harta karun dari kapal tenggelam, survei lokasi tenggelamnya kapal kuna, atau diskusi tentang arkeologi maritim. Kegiatan tersebut hampir semua dilakukan pihak ketiga, yaitu swasta dalam negeri yang melibatkan atau kerjasama dengan pihak asing. Barangkali hal ini sebabkan karena pemerintah merasa "tidak mampu" baik secara finansial maupun secara teknik untuk melakukan penelitian sendiri. Alasan ini pula yang membayangi lambatnya penanganan peninggalan bawah air oleh bangsa sendiri.

Kini saatnya untuk tidak hanya berpikir tetapi bertindak untuk menggali potensi dan merekonstruksi sejarah peninggalan bawah air di Nusantara. Wilayah Nusantara yang sebagian besar perairan diduga sangat besar potensi kandungan kapal karamnya. Berdasarkan sumber Litbang Oseanologi tercatat sekitar kurang lebih 463 titik situs bawah air, Arsip Organisasi Arkeologi di Belanda menginformasikan sekitar 245 kapal VOC, sedangkan Tony Wells, Shipwrecks \& Sunken Tresure menyebutkan ada sekitar 186 kapal VOC. Adapun sebaran titik tersebut terdapat di perairan Selat Malaka, Sumatra Selatan yang tersebar di Selat Bangka, Perairan Riau, Selat Gaspar, Perairan Belitung, Perairan Enggano, Kepulauan Seribu-Selat Sunda, Pelabuhan Ratu, Perairan Cilacap - Jawa Tengah, Laut Jawa, Perairan Karimun Jawa-Pantai Jepara, Selat Madura-Pulau Kangean, Selat Karimata, Nusa Tenggara Barat-Timur, Perairan Arafura, Perairan Irian Jaya, Perairan Morotai-Teluk Kao, Perairan Halmahera Tidore- Bacan, Perairan Ambon - Buru, Perairan Teluk Tomini dan Perairan Selat Makassar (Anonim. 2007).

Balai Arkeologi Yogyakarta dengan wilayah kerja meliputi Provinsi Daerah Istimewa Yogyakarta, Provinsi Jawa Tengah, dan Provinsi Jawa Timur, tentu hanya dapat melakukan kegiatan identifikasi potensi peninggalan bawah air secara terbatas di kawasan Laut Jawa dan 
Samudera Indonesia. Aktivitas survei arkeologi bawah air untuk memperoleh titik shipwrecks oleh Balai Arkeologi Yogyakarta secara mandiri belum pernah dilakukan, namun data hasil survei lembaga lain bisa dijadikan acuan awal. Tabel berikut merupakan contoh data potensi peninggalan bawah air di perairan Laut Jawa dan perairan Samudera Indonesia.

Tabel Data Obyek Penelitian Arkeologi Bawah Air

\begin{tabular}{|l|l|c|}
\hline No & \multicolumn{1}{|c|}{ Lokasi Perairan } & $\begin{array}{c}\text { Jumlah } \\
\text { Lokasi /Situs }\end{array}$ \\
\hline 1 & Perairan Jawa Tengah & 9 \\
\hline 2 & Karimun Jawa, Jepara & 14 \\
\hline 3 & Selat Madura & 5 \\
\hline 4 & Perairan Cilacap, Jawa Tengah & 51 \\
\hline & Jumlah & 79 \\
\hline
\end{tabular}

Sumber: Badan Riset Kelautan dan Perikanan, DKP

Berdasarkan tabel di atas, jumlah situs shipwrecks yang berada di kawasan kerja Balai Arkeologi Yogyakarta sedikitnya terdapat 79 situs. Jumlah tersebut tentu bisa lebih banyak dan bisa kurang untuk kepentingan penelitian arkeologi bawah air. Hal ini disebabkan karena data hasil riset Departemen Kelautan dan Perikanan (DKP) tersebut tidak menyebutkan jenis temuannya, serta apakah titik-titik temuan itu termasuk benda cagar budaya atau bukan. Kapal-kapal tenggelam di dalam hasil riset tersebut bisa jadi merupakan kapal-kapal yang relatif baru, sedangkan kapal-kapal kuna katagori sebagai benda cagar budaya tidak atau belum terdeteksi. Akan menjadi tantangan yang tidak ringan bagi penelitian arkeologi bawah air apabila sejumlah temuan kapal-kapal tenggelam tersebut seluruhnya termasuk benda cagar budaya.

\section{KEGIATAN YANG TELAH DILAKUKAN}

\section{Pengembangan SDM dan Sarana Penunjang}

Sebagai negeri kepulauan, sangat ironis bila pengembangan penelitian arkeologi bawah air di Indonesia sangat ketinggalan dibanding negara lain. Tingkat ketertinggalan tersebut sangat tidak sebanding dengan potensi obyek penelitian yang ada. Kegiatan dan perhatian terhadap peninggalan bawah air sebenamya pernah dimulai yaitu pada dekade 1980an, ketika Pusat Penelitian Arkeologi Nasional (Puslit Arkenas) melalui Departemen Pendidikan dan Kebudayaan telah berupaya memulai pengembangan penelitian bawah air dengan menyiapkan tenaga peneliti, 
teknisi, dan sarananya. Pada tahun 1985 sejumlah peneliti dan teknisi mengikuti pelatihan arkeologi bawah air di Thailand. Upaya ini perlu dilakukan karena disadari bahwa jumlah tenaga arkeologi bawah air di Indonesia waktu itu sangat terbatas. Pendidikan tenaga arkeologi bawah air di Thailand diselenggarakan oleh SEAMEO Project in Archaeology and Fine Art (SPAFA) dan meliputi pendidikan penyelaman, konservasi, dan fotografi.

Mengapa pengembangan penelitian arkeologi bawah air di Indonesia tertidur?, Ada beberapa keadaan yang menyebabkan keadaan ini terjadi. Pertama, penelitian arkeologi bawah air memiliki tingkat kesulitan yang lebih tinggi dan tingkat resiko keselamatan yang tinggi dibandingkan penelitian arkeologi di darat. Kedua, terbatasnya sumber daya manusia (SDM) yang terlatih. Ketiga, mahalnya perlengkapan sarana penunjang maupun pembiayaan operasional penelitian yang tinggi. Semua itu menjadi faktor yang menjadi kendala untuk melakukan penelitian arkeologi bawah air di Indonesia. Oleh karena itu jalan untuk menuju penelitian arkeologi bawah air tidak semudah membalikkan telapak tangan dan oleh karenanya perlu pentahapan menyiapkan kemampuan dari segala aspek.

Di sisi lain, kini ada harapan baru yang lebih cerah dengan makin meningkatnya minat generasi baru untuk mengembangkan dan menggali potensi peninggalan bawah air. Dimulai pada tahun 2006, Balai Arkeologi Yogyakarta secara bertahap mulai mengembangkan underwater archaeology. Aksi ini diawali dengan pengembangan SDM berupa pelatihan dan sertifikasi penyelaman, pengembangan dan pengadaan peralatan, serta pengembangan isu-isu arkeologi maritim. Selain itu, secara bertahap juga dibentuk unit khusus underwater archaeology yang terdiri atas para peneliti, teknisi, dan staf pendukung lain.

Setelah tiga tahun mempersiapkan bekal ketrampilan underwater archaeology, akhirnya Balai Arkeologi Yogyakarta telah sampai pada tahap untuk melaksanakan penelitian bawah air. Pada tahap awal sebagai dasar pengetahuan tentang penelitian arkeologi bawah air maka dilakukan penelitian perahu tenggelam di perairan Karimunjawa, Jepara, Jawa Tengah. Dasar kompetensi untuk pelaksanaan penelitian arkeologi bawah air yang ditetapkan oleh Balai Arkeologi Yogyakarta adalah sebagai berikut:

* SDM dengan sertifikasi POSSI (A1: 2 orang, A2: 5 orang, dan A3: 2 orang), dan belum sertifikasi 2 orang.

* Peralatan selam dan peralatan kerja arkelogi bawah air,

* Ada jaringan penyelaman antara: POSSI, TNI-AL, dan Club-club selam.

* Peningkatan ketrampilan spesialisasi dalam underwater archaeology (manajemen penyelaman, fotografi-videografi, pemetaan dan penggambaran, arkeologi maritim, dll.)

Seperti diketahui, kegiatan penelitian arkeologi bawah air memiliki kesulitan tinggi, sehingga resiko keselamatan personil tinggi apabila tidak dilakukan dengan tenaga terlatih dan disiplin tinggi. Langkah pertama mereka harus dibekali dengan ketrampilan penyelaman dan segala pengetahuan keselamatan penyelaman di laut lepas. 
Hanya berbekal minat dan antusiasme personil tentang arkeologi bawah air saja belum cukup. Mereka harus betul-betul mempunyai kemampuan yang memadai untuk menuju ke benda purbakala di bawah air. Oleh karena itu pembekalan ilmu, teknik, dan persiapan fisik lebih didahulukan. Tahapan selanjutnya adalah membuat rancangan kegiatan

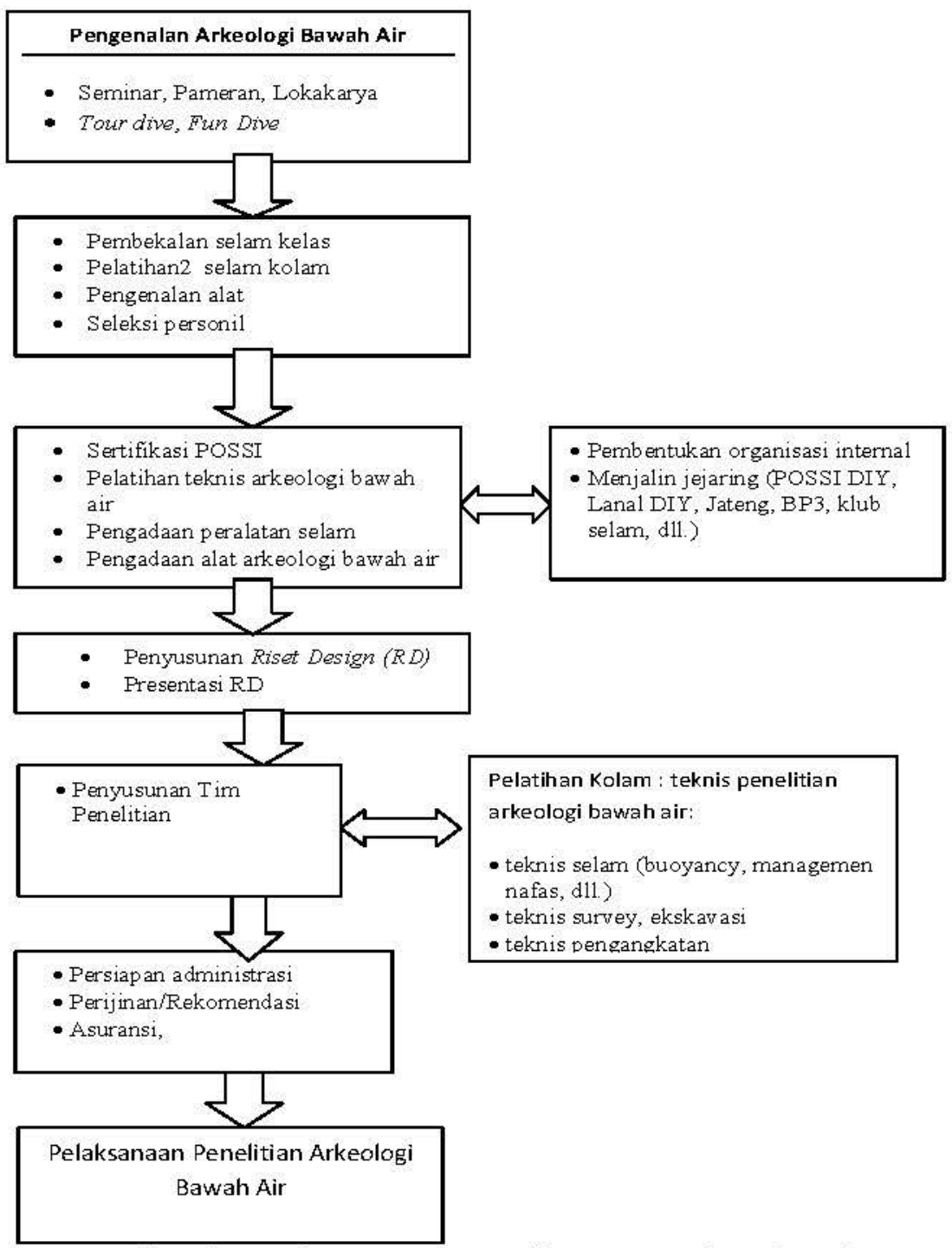

Bagan alir tahapan dan proses pengembangan penelitian bawah air di Balai Arkeologi Yogyakarta.

penelitian yang disesuaikan dengan kemampuan pengetahuan dan ketrampilan, serta melibatkan pihak lain yang lebih berkompeten. Urutan pentahapan pengembangan penelitian arkeologi bawah air di Balai Arkeologi Yogyakarta dalam bentuk bagan alir seperti dalam lampiran bagan alir di bawah. 
Upaya pengembangan SDM arkeologi bawah air di Balai Arkeologi Yogyakarta tidak terbatas untuk penelitian saja. Ketrampilan penyelaman (diving) harus terus menerus dilakukan untuk meningkatkan kemahiran dan untuk keselamatan penyelam. Oleh karena itu kegiatan penyelaman di luar kedinasan pun dapat diikuti, selain untuk menambah ketrampilan penyelam, penambahan jam selam juga untuk menjalin jejaring antar penyelam baik perorangan, lembaga, asosiasi maupun klub-klub. Sebagai contoh pada tanggal 17 Agustus 2009 mengikutsertakan anggota penyelam untuk mengikuti upacara bendera di bawah laut Bunaken - Manado. Keikutsertaan penyelam Balai Arkeologi Yogyakarta dalam kegiatan tersebut merupakan kebanggaan atas kepercayaan yang difasilitasi seluruhnya dari TNI-AL.

\section{Pengembangan Penelitian Arkeologi Maritim}

Sebagai negara kepulauan, Indonesia tidak boleh mengabaikan pentingnya penelitian sejarah maritim. Segera ada kesadaran bahwa wawasan bahari tidak hanya diperlukan untuk zaman yang lampau atau zaman bahari, melainkan sangat penting bagi eksistensi dan kelangsungan hidup suatu negara kepulauan (Koestoro, $t t)$. Untuk merekonstruksi sejarah maritim diperlukan data, sedangkan data yang relatif aman adalah data arkeologis yang masih berada di dalam laut. Renfrew \& Bahn (1991) menyatakan bahwa pada beberapa kesempatan, sumber terkaya dari bukti arkeologi mengenai peristiwa sejarah itu diperoleh melalui sisa bangkai perahu yang terpelihara dalam lingkungan tempat obyek tersebut berada yang berhasil diliput melalui kerja arkeologi maritim.

Penelitian arkeologi maritim di Balai Arkeologi Yogyakarta dalam riwayatnya memang pernah dilakukan antara tahun 1995 s.d. 1998. Ketika itu, penelitian arkeologi maritim lebih ditekankan kepada kajian keterkaitan budaya antara kepulauan di perairan utara Jawa dengan budaya Jawa. Setelah itu terjadi kevakuman kegiatan penelitian arkeologi maritim, kemudian kegiatan baru diawali kembali dengan adanya temuan perahu kuna di Desa Punjulharjo, Kecamatan Rembang, Kabupaten Rembang, Jawa Tengah. Penelitian arkeologi pada perahu tersebut bertujuan untuk mengungkap informasi arkeologis yang melekat pada perahu kuna. Sisasisa perahu dalam bentuk apapun akan memberikan informasi yang penting setelah melalui penelitian arkeologi. Atribut-atribut yang melekat pada perahu dan artefak sertaan lainnya merupakan data penting untuk diungkap melalui penelitian. Misalnya, analisis teknologi rancang bangun perahu. Melalui hasil rekonstruksi rancang bangun perahu juga dapat diketahui periodisasi perahu saat kapan masih aktif digunakan, fungsi perahu, berapa kisaran berat muatannya, berapa jarak jelajahnya, serta apa saja muatannya. Setelah dilakukan penelitian pada bulan Juni 2009 hasil sementara diperoleh gambaran bahwa rancang bangun atau model perahu Punjulharjo Rembang adalah "teknik papan-ikat dan kupingan-pengikat", dalam istilah asing disebut "sewn-plank and lashed-lug technique". Teknik pembuatan perahu demikian berkembang di Asia Tenggara sehingga sering disebut juga teknik tradisi Asia Tenggara (Manguin, 1985). 
Kegiatan-kegiatan yang telah dilakukan tersebut di atas adalah gambaran kesiapan lembaga penelitian arkeologi untuk mengembangkan penelitian arkeologi bawah air dengan serius. Banyak celah yang belum terisi akan diupayakan untuk dilengkapi dalam rangka pengembangan penelitian arkeologi maritim di Indonesia. Kegiatan yang sudah dilakukan akan selalu dievaluasi, dan terbuka bagi masukan dan kritik dari pihak lain demi kesempurnaan kegiatan atau tugas yang tidak ringan tersebut.

\section{PENUTUP}

Merubah paradigma orientasi penelitian arkeologi darat ke orientasi penelitian arkeologi bawah air di Indonesia tidak mudah. Penelitian arkeologi yang telah bertahun-tahun mengeksplorasi peninggalan arkeologi di darat pun masih banyak tantangan yang tidak mudah, apalagi menengok ke arah eksplorasi peninggalan di bawah air. Paradigma penelitian arkeologi untuk mengungkap sejarah peradaban di Nusantara seharusnya menyeluruh dan tidak terkotak-kotak. Oleh karena itu kini saatnya penelitian arkeologi bawah air yang penuh hambatan dan banyak kelemahan (weakness) dijadikan tantangan (challenge) tersendiri, dan bagaimana tantangan tersebut bisa dijadikan peluang (opportunity) ke depan untuk pengembangan penelitian arkeologi maritim Nusantara.

Pengembangan penelitian arkeologi bawah air di Indonesia tidak sekedar mengungkap sejarah budaya kemaritiman Nusantara saja, namun di balik kegiatan itu diperlukan persyaratan yang tidak mudah dan tidak murah. Minat yang besar dan ilmu yang tinggi belum bisa menjadi modal yang cukup untuk meraih keberhasilan penelitian arkelogi bawah air. Persiapan sumber daya manusia di bidang ketrampilan (skills), penambahan wawasan teknis dan akademis, perencanaan strategis, koordinasi dan menciptakan jejaring dengan lain pihak, menciptakan insan underwater archaeology yang komitmen dan mampu bekerjasama secara kompak baik di bawah air maupun di atas air, adalah kebutuhan yang standar sebagai modal pengembangan penelitian. Di lain pihak persiapan instrument penelitian dan penyelaman yang jauh berbeda dengan instrumen penelitian di darat secara bertahap harus memenuhi kebutuhan dasar dengan kualitas standar minimal.

Memulai dari segala keterbatasan namun tidak mengabaikan nilai ilmiah dan keselamatan adalah lebih baik daripada menunggu kondisi ideal tercipta tanpa kepastian. Karena itu, semangat pengembangan arkeologi bawah air di Balai Arkeologi Yogyakarta, yang dimulai pada awal tahun 2006, akan dijadikan tonggak awal perintisan pengelolaan peninggalan bawah air dalam bentuk penelitian. Aspek penelitian arkelogi bawah air yang tidak sedikit berkaitan dengan aspek lain yang saling menunjang dan saling melengkapi merupakan sebuah tantangan. Oleh karena itu penelitian arkeologi bawah air dengan segala aspeknya akan menjadi salah satu kegiatan strategis pengelolaan benda arkeologis peninggalan di bawah air. 
Karena merupakan kegiatan strategis maka perlu langkah-langkah strategis pula, dengan demikian perlu perencanaan yang akan dituangkan dalam rencana strategik (Renstra) Balai Arkeologi Yogyakarta 2010-2014.

Sebagaimana diuraikan di atas, kebijakan pengembangan penelitian arkeologi bawah air di Balai Arkeologi Yogyakarta dapat dirumuskan sebagai berikut.

1. Mengarahkan dan menambah wawasan tentang paradigma serta orientasi penelitian arkeologi maritim (bahari),

2. Menyiapkan sumber daya manusia professional di bidang kajian arkeologi maritim dan ketrampilan penyelaman (diving), serta membuka peluang pengembangannya.

3. Pembentukan kelompok interen peminat profesi penyelaman dan profesi penunjang penelitian bawah air,

4. Memfasilitasi latihan penyelaman secara kontinyu dan pengikutsertaan anggota penyelam dalam kegiatan (event) penyelaman di luar penelitian,

5. Pengadaan peralatan penyelaman dan peralatan penunjang penelitian arkeologi bawah air yang sesuai operasional dan proporsional dengan standard minimal,

6. Menjalin jejaring (networking) dan kerjasama dengan stakeholders yang berkaitan dengan kajian arkeologi maritim maupun penyelaman,

7. Menuangkan kebijakan perencanaa penelitian arkeologi bawah air ke dalam rancangan strategis Balai Arkeologi Yogyakarta.

8. Melakukan evaluasi secara periodik seluruh kegiatan setahun sekali untuk peningkatan kinerja. 


\section{KEPUSTAKAAN}

Anonim, 2007. Jalan Panjang Menuju Arkeologi Bawah Air. http://celebesarchaeology.wordpress.com

tt. Departemen Kelautan dan Perikanan. http://statistik.dkp.go.id/download

Green. Jeremy. 2004. Maritime Archeology - A Technical Handbook. Second edition. ELSEVIER Academic Press. Amsterdam - Boston Heidelberg - London-New York - Oxford - Paris - San Diego - San Francisco - Singapore - Sydney - Tokyo.

Koestoro, Lucas Partanda. tt. Arkeologi dan Pengenalan Prasejarah Perahu Nusantara. balarmedan.wordpress.com

Lombard, Denys. 2005. Nusa Jawa: Silang Budaya - Bagian II: Jaringan Asia. Gramedia Pustaka Utama - Forum Jakarta-Paris - Ecole Francaise d'Extreme-Orient (EFEO).

Manguin, P.Y., 1985. "Sewn-plank Craft of Southeast Asia. A Preliminary Survey", in Sewn Planked Boats. Archaeological and Ethnographic papers on those presented to a conference at Greenwich in November, 1984. Sean McGrail and Eric Kentley (eds.). National Maritime Museum, Greenwich, Archaeological Series No. 10. BAR International Series 276 .

Renfrew, Colin \& Paul Bahn, 1991. Archaeology. Theories, Methods, And Practice. London: Thames and Hudson.

Tanudirjo, Daud Aris. 2008. "Awal Jaringan Pelayaran dan Perdagangan" dalam Kapal Karam Abad ke-10 di Laut Jawa Utara Cirebon. Bambang Budi Utomo (ed.) PANNAS-BMKT, Jakarta. 